\title{
Confessions of a Bad Dog
}

\author{
I confess \\ I am a bad dog... \\ I do not obey the rules \\ and no matter how much love \\ or how many comforts you give me \\ I will not do tricks \\ or beg \\ or amuse you. \\ Sometimes you will think \\ I am beginning to learn, \\ I will retrieve my leash \\ and ask you to go for a walk \\ I will bark at strangers \\ and bury some bones \\ I will be a good dog \\ and you will think I am happy. \\ But this can't last long... \\ One day you will find me \\ rolling in your rose garden \\ or sleeping on your best sheets \\ or licking your tuna spinach lasagna \\ off my lips. \\ I confess, \\ I will put a sad face \\ my most apologetic eyes \\ will focus into space \\ and its truly not \\ to simply calm your disapproval \\ I really do wish to hear, \\ Good dog!
}


But I must confess,

all this wagging and pleasing

so much retrieving and releasing

and so many strict little lines

within which you encase rules

Encase me!

\author{
And perhaps \\ Your spectacles are old \\ because since we met \\ I have hoped \\ you would see \\ I am not a $\operatorname{dog} . .$. \\ Meow!
}

Tania Guerrero 